\title{
Viral Bad News Sent by EVAIL
}

\author{
Matthias Clauss ${ }^{1, *}$, Sarvesh Chelvanambi ${ }^{2,+},{\text { Christine } \text { Cook }^{3, \dagger}, \text { Rabab ElMergawy }^{1} \text { and Navneet Dhillon }}^{3}$ (D) \\ 1 IU School of Medicine, Pulmonary, Critical Care, Sleep and Occupational Medicine, \\ Indianapolis, IN 46202, USA; rgelmerg@iu.edu \\ 2 Brigham and Women's Hospital, Department of Medicine, Boston, MA 02115, USA; \\ schelvanambi@bwh.harvard.edu \\ 3 Pulmonary and Critical Care Medicine, University of Kansas Medical Center, Kansas City, KS 66160, USA; \\ ccook3@kumc.edu (C.C.); NDHILLON@kumc.edu (N.D.) \\ * Correspondence: mclauss@iu.edu or mclaus@iupui.edu \\ + These authors contributed equally.
}

check for updates

Citation: Clauss, M.; Chelvanambi, S.; Cook, C.; ElMergawy, R.; Dhillon, N. Viral Bad News Sent by EVAIL. Viruses 2021, 13, 1168. https:// doi.org/10.3390/v13061168

Academic Editor: Francesca Caccuri

Received: 22 April 2021

Accepted: 9 June 2021

Published: 18 June 2021

Publisher's Note: MDPI stays neutral with regard to jurisdictional claims in published maps and institutional affiliations.

Copyright: (c) 2021 by the authors. Licensee MDPI, Basel, Switzerland. This article is an open access article distributed under the terms and conditions of the Creative Commons Attribution (CC BY) license (https:/ / creativecommons.org/licenses/by/ $4.0 /)$.

\begin{abstract}
This article reviews the current knowledge on how viruses may utilize Extracellular Vesicle Assisted Inflammatory Load (EVAIL) to exert pathologic activities. Viruses are classically considered to exert their pathologic actions through acute or chronic infection followed by the host response. This host response causes the release of cytokines leading to vascular endothelial cell dysfunction and cardiovascular complications. However, viruses may employ an alternative pathway to soluble cytokine-induced pathologies—by initiating the release of extracellular vesicles (EVs), including exosomes. The best-understood example of this alternative pathway is human immunodeficiency virus (HIV)-elicited EVs and their propensity to harm vascular endothelial cells. Specifically, an HIV-encoded accessory protein called the "negative factor" (Nef) was demonstrated in EVs from the body fluids of HIV patients on successful combined antiretroviral therapy (ART); it was also demonstrated to be sufficient in inducing endothelial and cardiovascular dysfunction. This review will highlight HIV-Nef as an example of how HIV can produce EVs loaded with proinflammatory cargo to disseminate cardiovascular pathologies. It will further discuss whether EV production can explain SARS-CoV-2-mediated pulmonary and cardiovascular pathologies.
\end{abstract}

Keywords: extracellular vesicles; viral infection; HIV; SARS-CoV-2; Nef; antiretroviral therapy; cardiovascular disease

\section{Introduction}

For many years, acute and chronic viral infections have been associated with the development of cardiovascular disease (CVD). For example, infectious encounters with cytomegalovirus (CMV) correlate with a $22 \%$ increased risk for future development of cardiovascular disease [1]. However, the contribution and the biology of viruses towards CVD are incompletely understood. What is extraordinarily well studied is infection with Human Immunodeficiency Virus-1 (HIV) and how it may affect cardiovascular health. Notably, after the introduction of antiretroviral therapy (ART), cardiovascular disease (CVD) became a leading cause of death in the HIV-positive population [2]. Because the HIV biology concerning cardiovascular and pulmonary diseases is so well understood, it may serve as a blueprint for studying other viruses with known impacts on CVD. This review focuses specifically on the role of extracellular vesicles (EVs) in HIV infection and their possible CVD contribution. Finally, using the example of the pandemic SARS-CoV-2 virus, it tries to apply what we have learned about HIV-induced EV formation to understand SARS-CoV-2 virus-induced CVD (see Figure 1). 


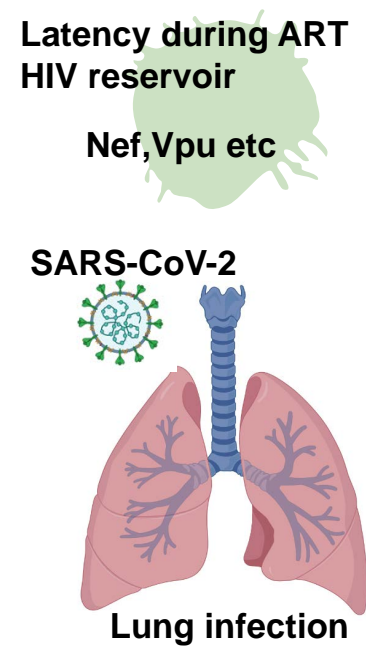

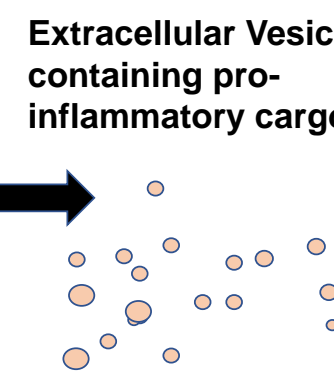

Uptake of proinflammatory cargo by endothelial cells



Pro-inflammatory cargo of proteases and cytokines causes Endothelial Cell Activation

\section{Pro-inflammatory Activation \\ Vascular Pathologies}

VCAM-1 Tissue ICAM-1 factor
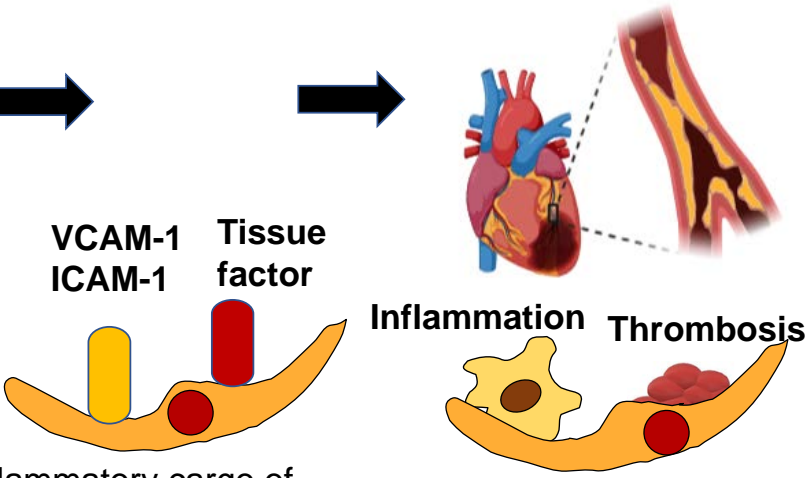

Endothelial Cell Dysfunction

Figure 1. Proposed role of EVs in HIV-associated CVD and SARS-CoV-2 caused pathologies.

\section{HIV Mystery: Heightened CVD Risk in HIV-Infected Individuals on ART}

2.1. Persistent CVD Risk in HIV-Infected Individuals Despite ART

The HIV-associated risk of developing CVD persists despite the initiation of ART [3-6]. For example, atherosclerotic conditions continue to progress more in the HIV population after ART is initiated based on arterial carotid intima-media thickness [7]. Further, a more recent large meta-analysis combining five studies and 89,713 subjects concluded that "stroke represents a relatively common complication in young HIV patients" [8]. Another example is primary pulmonary arterial hypertension (PAH); the prevalence of $\mathrm{PAH}$ was determined as $0.5 \%$ during the pre-ART era [9] and stayed high $(0.46 \%)$ in the era of ART [10]. These are alarming numbers, given that the prevalence of PAH in the general population is $0.0015 \%$. An overview about studies assessing the risk of HIV patients on ART for developing CVD is depicted in Table 1.

Table 1. List of studies describing the increased risk for various CVD in HIV patient cohorts on Anti-Retroviral Therapy.

\begin{tabular}{|c|c|c|c|}
\hline Study & Country & $\begin{array}{l}\text { No. of HIV + } \\
\text { Patients }\end{array}$ & Outcome \\
\hline $\begin{array}{l}\text { Lang et al. [11] } \\
\qquad(2010)\end{array}$ & France & 74,958 & $\begin{array}{c}\text { Myocardial Infarction (Standardized Morbidity } \\
\text { Ratio 1.5) }\end{array}$ \\
\hline \multirow{2}{*}{$\begin{array}{l}\text { Hsue et al. [12] } \\
\qquad(2010)\end{array}$} & \multirow{2}{*}{ USA } & \multirow{2}{*}{196} & $\begin{array}{l}\text { Left Ventricular Mass Index }(77.2 \mathrm{~g} / \mathrm{m}(2) \text { vs. } 66.5 \mathrm{~g} / \mathrm{m} \\
\text { (2) } p<0.0001)\end{array}$ \\
\hline & & & Diastolic Dysfunction (50\% vs. $29 \% p=0.008$ ) \\
\hline $\begin{array}{l}\text { Durand et al. [13] } \\
\text { (2010) }\end{array}$ & Canada & 7053 & $\begin{array}{c}\text { Acute Myocardial Infarction (Adjusted Incidence } \\
\text { Ratio 2.11) }\end{array}$ \\
\hline $\begin{array}{l}\text { Butt et al. [14] } \\
\qquad(2011)\end{array}$ & USA & 2391 & Heart Failure (Hazard Ratio 1.81) \\
\hline $\begin{array}{l}\text { Sliwa et al. [15] } \\
\text { (2012) }\end{array}$ & South Africa & 518 & Pericarditis $(13 \%$ vs. $1.2 \%, p<0.001)$ \\
\hline $\begin{array}{l}\text { Lorgis et al. [16] } \\
\qquad(2012)\end{array}$ & USA & 608 & Ischemic Cardiomyopathy ( $7.6 \%$ vs. $4.2 \% p=0.02)$ \\
\hline $\begin{array}{c}\text { Freiberg et al. [17] } \\
\text { (2013) }\end{array}$ & USA & 27,350 & Acute Myocardial Infarction (Hazard Ratio 1.48) \\
\hline
\end{tabular}


Table 1. Cont.

\begin{tabular}{|c|c|c|c|}
\hline Study & Country & $\begin{array}{l}\text { No. of HIV + } \\
\text { Patients }\end{array}$ & Outcome \\
\hline $\begin{array}{l}\text { Womack et al. [18] } \\
\qquad(2014)\end{array}$ & USA & 710 & Cardiovascular Disease Outcome $($ Hazard Ratio $=2.8)$ \\
\hline $\begin{array}{l}\text { Luo et al. [19] } \\
\qquad(2014)\end{array}$ & China & 325 & $\begin{array}{l}\text { Diastolic Dysfunction (Prevalence } 16.5 \% \text { vs. } 7.2 \% \text {, } \\
\qquad p=0.027)\end{array}$ \\
\hline $\begin{array}{l}\text { Fontes-Carvalho et al. [20] } \\
\qquad(2015)\end{array}$ & Portugal & 206 & $\begin{array}{l}\text { Diastolic Dysfunction (Prevalence } 19 \% \text { vs. } 3.3 \% \text {, } \\
\qquad p<0.05 \text { ) }\end{array}$ \\
\hline $\begin{array}{l}\text { Rasmussen et al. [21] } \\
\text { (2015) }\end{array}$ & Denmark & 3251 & Myocardial Infarction (Incidence Rate Ratio 1.78) \\
\hline $\begin{array}{l}\text { Chow et al. [22] } \\
\text { (2015) }\end{array}$ & USA & 100 & $\begin{array}{l}\text { Subclinical Atherosclerosis (mean Coronary Artery } \\
\text { Calcium Score, Relative Risk }=1.20, p<0.05 \text { ) }\end{array}$ \\
\hline $\begin{array}{l}\text { Al-Kindi et al. [23] } \\
\text { (2016) }\end{array}$ & USA & 36,400 & Heart Failure (Relative Risk 1.66) \\
\hline \multirow{2}{*}{$\begin{array}{l}\text { Freiberg et al. [24] } \\
\qquad(2017)\end{array}$} & \multirow{2}{*}{ USA } & \multirow{2}{*}{31,523} & HFpEF (Hazard Ratio 1.21) \\
\hline & & & HFrEF (Hazard Ratio 1.61) \\
\hline $\begin{array}{l}\text { Knudsen et al. [25] } \\
\qquad(2018)\end{array}$ & Denmark & 908 & Peripheral Artery Disease (Adjusted Odds Ratio 1.9) \\
\hline \multirow{4}{*}{$\begin{array}{l}\text { Alonso et al. [26] } \\
\qquad(2019)\end{array}$} & \multirow{4}{*}{ USA } & \multirow{4}{*}{19,798} & Stroke (Hazard Ratio 2.3) \\
\hline & & & Myocardial Infarction (Hazard Ratio 1.2) \\
\hline & & & Heart Failure (Hazard Ratio 2.8) \\
\hline & & & Atrial Fibrillation (Hazard Ratio1.3) \\
\hline $\begin{array}{l}\text { Beckman et al. [27] } \\
\qquad(2019)\end{array}$ & USA & 28,714 & Peripheral Artery Disease (Hazard Ratio 1.19) \\
\hline $\begin{array}{l}\text { Rao et al. [28] } \\
\qquad(2019)\end{array}$ & Various & $248,145^{*}$ & Acute Myocardial Infarction (Relative Risk 1.96) \\
\hline \multirow{2}{*}{$\begin{array}{l}\text { Chattranukulchai } \\
\text { et al. [29] }\end{array}$} & \multirow{2}{*}{ Thailand } & \multirow{2}{*}{298} & Diastolic Dysfunction (Adjusted Odds Ratio 3.5) \\
\hline & & & LV Hypertrophy (Adjusted Odds Ratio 1.91) \\
\hline \multirow[b]{2}{*}{ Gaspar Vallilo et al. [30] } & \multirow[b]{2}{*}{ Brazil } & \multirow[b]{2}{*}{148} & LV Dilation and ART (Adjusted Odds Ratio 0.98) \\
\hline & & & $\begin{array}{c}\text { Septal Hypertrophy and ART (Adjusted Odds } \\
\text { Ratio 0.96) }\end{array}$ \\
\hline \multirow{2}{*}{ Shen et al. [31] } & \multirow{2}{*}{ China } & \multirow{2}{*}{587} & $\begin{array}{l}\text { ST-T segment elevation and ART (Adjusted Odds } \\
\text { Ratio 0.96) }\end{array}$ \\
\hline & & & $\begin{array}{l}\text { All ECG abnormality and ART (Adjusted Odds } \\
\text { Ratio 0.95) }\end{array}$ \\
\hline
\end{tabular}

* = pooled meta-analysis from 16 studies.

\subsection{Factors Contributing to CVD Risk in HIV-Infected Individuals on ART}

What are the possible explanations for this persistently increased risk for CVD in the HIV-positive population? One possibility is toxicity and dyslipidemia from antiretroviral drugs, as reviewed previously [32]. Typically, nucleoside- and non-nucleoside-based reverse transcriptase inhibitors are combined, with or without the addition of integrase or HIV-protease-targeting inhibitors. The latter, in particular, have displayed pronounced toxicity and are now mostly out of use [33]. Typically, newer ART regimens have less toxicity and are more efficient than early HIV replication inhibitors [32,34].

Another possible explanation why inflammation persists during ART could be that HIV infection irreversibly damages the mesenteric lymphatic system. This way, microbial translocation may continue after ART initiation, possibly leading to chronic inflammation $[35,36]$. In this context, the link between systemic inflammation and vascular health 
was the topic of the "Strategic Timing of Anti-Retroviral Therapy" (START) trial, in which HIV patients on successful ART demonstrated a correlation between inflammatory plasma markers and impaired arterial elasticity [37]. Interestingly, elevated markers of endothelial dysfunction have been found in patients with ART-controlled viral loads [38].

Increased CVD risk in HIV-infected patients may also be caused by virus-induced dyslipidemia, which is highly prevalent among patients living with chronic HIV infection [39]. Interestingly, HIV-Nef was suggested as the main viral factor associated with HIV-linked dyslipidemia [40-42]. Because Nef protein production appears to be relatively resistant to ART, this viral protein could explain persistent dyslipidemia in ART patients (see upcoming chapters on HIV-Nef persistence).

Last but not least, HIV in latent or actively infected cells could elicit the production and release of EVs $[43,44]$. Studies have suggested EVs mediated cardiovascular dysfunction in transferring its protein and non-coding RNA cargo to vascular endothelial and smooth muscle cells $[43,45]$. Several reports have demonstrated that the HIV-encoded Nef protein organizes EV formation and uses them as vehicles for dissemination [46-52]. These Nefcontaining EVs are toxic to surrounding cells, including bystander CD4 positive T cells and vascular endothelial cells that absorb them and become apoptotic [46-48,52]. These possible effects of HIV-associated EVs will be discussed in more detail in the following chapters.

\section{Increased EV in HIV-Infected Individuals Despite ART}

\subsection{EVs Are Enriched in the Plasma of HIV Patients on ART}

The term extracellular vesicles (EV) defines different types of vesicles secreted outside of the cell, including exosomes, microvesicles, and apoptotic bodies [53]. Because EVs are taken up by blood and tissue cells, they could spread proinflammatory cargo and HIV proteins throughout the body. Exosomes are reported as a subpopulation of EVs associated with HIV activities, including inflammation and dyslipidemia [54-61]. Of note, Lee et al. [62] showed that in HIV patients-whether viremic or on combined high dose antiretroviral therapy (ART) -EV numbers were approximately 20-fold higher over healthy controls. Similarly, the cargo load of these EVs from HIV increased 18-25-fold over otherwise healthy controls. As for cargo load, the authors determined the expression of miRNA and protein [62]. Support for the significance of these findings came from further studies using unbiased proteomic approaches and miRNA analysis to demonstrate that isolated plasma EVs contained markers "associated with immune activation and oxidative stress in HIV patients on ART" [44,63].

\subsection{Nef Protein Persists in EVs from Body Fluids}

Given the presence and upregulation of EVs in the HIV-positive population, "early response" HIV genes including Nef, tat, and rev were suspected. These "early" HIV genes decrease after initiation of ART treatment less prominently than other HIV gene products [64]. Intracellular mRNA-encoding Nef levels were maintained during ART, while Tat and Rev showed less prominent mRNA expression [65].

Nef protein inside CD45+ EVs in the plasma of HIV-infected individuals was first reported in 2011 by Raymond et al. [66]. Subsequent studies have detected Nef protein in EVs from plasma and peripheral blood mononuclear cells (PBMCs) of both treatment-naive HIV patients and HIV-infected individuals on ART with undetectable viral loads [47,67]. Interestingly, HIV-Nef was detected in over half the patients on ART and in elite controllers in a study using $134 \mathrm{HIV}$-infected patients with undetectable HIV RNA [68]. Our previous work could confirm these findings in a much smaller study of 16 patients on ART, in which also about half were HIV-Nef-positive [47]. Interestingly, we also found high numbers of Nef protein-positive PBMCs using flow cytometry and a panel of three monoclonal antibodies targeting three different and highly conserved epitopes because of the high mutation rate of HIV. 


\subsection{Nef Protein in EVs Transfers Rapidly to Blood and Tissue Cells}

The presence of Nef in both EVs and PBMC begs the question of whether mononuclear cells are the target or source of Nef-containing EVs. Apparently, Nef can be transported by EVs and transferred to PBMCs and endothelial cells because it is present to a large extent in B cells and CD4- T cells, and Nef-positive PBMCs transferred Nef rapidly to vascular endothelial cells in vitro [47,67]. Further support for the hypothesis that mononuclear cells are the target of Nef-containing EVs comes from our previous work demonstrating the presence of Nef protein in EVs and cells derived from bronchoalveolar lavages (BAL) [46]. While $50 \%$ of the patients (10 out of 18) displayed Nef-EV positivity based on ELISA, Nef positive BAL cells were randomly distributed between alveolar macrophages, CD4+ T cells, and CD8+ T cells (in nine out of 15 HIV patients on ART).

To date, the source (or sources) of these surprisingly robust levels of Nef protein in successfully ART-treated patients remains unclear. Lee et al. [62] suggested a myeloid or myeloid-like compartment as the origin of Nef-induced EV formation, based on protein array analysis of patient-derived plasma EVs, which was different from those in EVs derived from HIV-transfected Jurkat cells. A closer identification of this compartment could help in understanding HIV latency in the era of ART.

\section{HIV-Nef Induces Extracellular Vesicle-Assisted Inflammatory Load (EVAIL)}

\subsection{Specific Surface Proteins in EVs Define Proinflammatory Cargo Associated with HIV Proteins}

Given the 20-fold increase in EV numbers and protein load found in plasma from HIV patients on ART, researchers asked whether HIV proteins could be linked to specific EV surface markers. To address this, Lee et al. [62,69] tested a panel of 262 monoclonal antibodies coupled to magnetic beads for their ability to adsorb plasma-derived EV with HIV cargo. They could identify one antibody (clone 2H4) that captured all EVs containing $\mathrm{HIV}$ proteins (Nef and $\mathrm{Vpu}$ ). Interestingly, this antibody was identified to recognize activated $\alpha \mathrm{v} \beta 3$, an angiogenic integrin also known as vitronectin receptor, and associated with macrophages' phagocytic activity. Further, this study found that activated $\alpha v \beta 3$ positive EVs contained the proinflammatory matrix-metalloproteinases ADAM-17 (TACE) and ADAM-10, absent in the unbound fraction. Subsequently, Nef- and TACE-containing EVs were isolated from HIV patients, which, in turn, correlated with immune pathogenesis in chronic HIV-infected patients [62].

Interestingly, the presence of Extracellular Vesicle Assisted Inflammatory Load (EVAIL) includes a specific pattern consisting of cytokines, chemokines, and growth factors, such as PDGF BB and FGF-9 [62]. In conclusion, a particular EV surface protein emerged as a potential biomarker for HIV-associated EVs carrying inflammatory cargo. However, there is a gap of knowledge regarding the Nef-associated composition of non-coding RNAs, including miRNAs, which were reported to be modulated in HIV-induced EVs [43,44].

\subsection{Nef Initiates Endosomal Routing Leading to Recruitment of ADAM-17/TACE and Secretion of TNF}

Ostalecki et al. [70] showed that uptake of these Nef-containing EVs induced endosomal TNF cleavage by TACE. They identified as the first step Nef-dependent internalization of TACE in Rab4+ early endosomes. This enabled compartmentalization with transmembrane $\mathrm{TNF} \alpha$, which was followed by TACE activation, TNF $\alpha$ cleavage, and secretion as $\mathrm{TNF} \alpha / \mathrm{TACE}$ repackaged EVs [70]. TNF $\alpha$ maintains at intravesicular location, which is different from the canonical TNF $\alpha$ release as a soluble protein from cells. These findings are significant as TACE is the primary mechanism driving the release of mature TNF $\alpha$ and the primary driver of other proinflammatory pathways involved in chronic inflammation and its associated diseases [71]. They also show that Nef is associated with vesicle sorting. It is likely that Nef orchestrates the loading of proteases and cytokines in EVs. Alternatively, the host system could interpret Nef as a danger signal to load Nef-containing EVs with proteases and cytokines in preparation to fight infectious agents. 


\section{Pathophysiology of the HIV-Nef-Associated EVAIL}

The elucidation of pathogenic mechanisms in HIV-associated comorbidities in the era of ART is still incompletely understood, as is the function of HIV-released EVs. The release of pathogenic HIV proteins like Nef into the systemic circulation through ADAM17/TACEcontaining EVs could be advantageous for HIV by activating latent viral activity $[72,73]$. Likewise, ADAM-17/TACE-induced v generation can prime resting CD4+ T lymphocytes for HIV expression and replication $[50,69,70]$. As it would make evolutionary sense for the virus to promote its infectivity broadly, could it be that the same TACE-induced TNF $\alpha$ generation causes endothelial activation and dysfunction more like an unwanted side effect? Indeed, Nef-containing EVs can affect recipient cells both on functional and gene expression levels [46-48,62,74,75]. Khan et al. [76] isolated Nef-EVs from HIV patients with HIV-associated dementia (HAD) and demonstrated that they could elicit increased $A \beta$ secretion from neuronal cells. Reportedly, Nef-containing EVs are indeed taken up by neuronal cells leading to oxidative stress [75].

EVs must not necessarily have to reach distal organs to increase proinflammatory pathologies. Alternatively, microglia cells could produce and release such EVs. Raymond et al. [77] demonstrated that EVs could cross the blood-brain barrier. In addition, they found that microglial cells transfected with Nef released Nef-EV to reduce the endothelial blood-brain barrier. This loss of barrier function is likely due to Nef-EV reducing tight junction protein expression, ZO-1. Importantly, this study demonstrated that by using a specific Nef-peptide inhibitor, Nef-EV-induced disturbance of their blood-brain barrier model can be reversed [77]. These findings indicate that HIV reservoir cells in the brain can employ HIV-Nef release to contribute to HIV-associated neurocognitive diseases (HAND). Furthermore, they could also promote cardiovascular disease as EVs produced from brain cells cross the BBB also in reverse.

As another example of the proinflammatory propensity of EVs, the addition of NefEVs to peripheral blood monocytes (PBMCs) led to TNF $\alpha$-converting enzyme (TACE/ ADAM17) packaging into vesicles and subsequent secretion [69]. Uptake of Nef-EVs in $T$ cells from human PBMCs causes free radical formation and apoptosis when these cells are brought in close contact with human coronary arterial endothelial cells. This finding suggests that leukocytes can further enhance HIV-Nef-induced pathologies [47].

Wang et al. [48] were the first to report that Nef is transported from T cells to endothelial cells to cause reactive oxygen species (ROS) production, upregulation of chemokines, and pro-apoptotic signaling. Interestingly, T cells infected with HIV elicited the same panel of endothelial activation markers, which was either absent or much reduced when HIV with a deleted Nef gene was used.

Further, Nef-containing EVs from BAL fluids and Nef-transfected cells were shown to induce programmed cell death in endothelial cells, dependent on induction of EMAP II [46]. Interestingly, transgenic expression of Nef in the endothelium induced endothelial EMAP II surface expression, which could mediate the emphysema phenotype in these transgenic mice.

Furthermore, our own previous work has shown that HIV-Nef expressing T cells and HIV-Nef-induced EVs upregulated endothelial adhesion proteins and apoptosis. This upregulation occurred together with cytosolic dyes and Nef protein transfer from $\mathrm{T}$ to endothelial cells, dependent on Rac1-activation [47]. These Rac1-dependent activities were characterized by the production of NADPH/NOX2-mediated reactive oxygen species (ROS). Statin treatment equally inhibited Rac1 inhibition in preventing or reversing HIVNef-induced ROS formation, mitochondrial polarization, and increased pro-apoptotic signaling in human coronary arterial endothelial cells [47]. This therapeutic effect was explained by the ability of statins to block Rac1 prenylation. Indeed, geranylgeranyl transferase inhibitors significantly reduced HIV-Nef-induced ROS formation. These findings suggest a protective role of statins beyond lipidemia. Certainly, there is clinical evidence of the positive effects of statins in combination with ART in HIV/AIDS patients, thus the 
recommendation that statin treatment should be considered in this population after due attention to possible drug-drug interactions [78].

In addition to the ability of Nef-EVs to induce endothelial cell activation and increased stickiness of proinflammatory leukocytes to vascular endothelial cells even under conditions of flow [47], they can increase cholesterol and triglyceride levels [40-42]. Cholesterol levels are known to be regulated by reverse cholesterol transport. Reportedly, Nef mediates the down-regulation of adenosine triphosphate-binding cassette transporter A1 (ABCA1) transporters by post-translational degradation [42]. In apoE $(-/-)$ mice, injected Nef reduced levels of ABCA1 in the liver, supporting the link between Nef and increased cholesterol plasma levels [41]. Not surprisingly, these effects occurred together with increased atherosclerotic lesion size and blood vessel remodeling.

Furthermore, the results of Nef on dyslipidemia could be replicated in the SIV-infected macaque model [40]. SIV infection down-regulated the ABCA1 cholesterol transporter in the liver, and serum from SIV-infected but not from healthy macaques inhibited cholesterol efflux from human cultivated macrophages. Interestingly, Nef-induced ABCA1 downregulation goes beyond regulation of lipid levels: Mukhamedova et al. [79] could demonstrate that Nef-induced ABCA1 downregulation results in increased abundance of lipid rafts in monocytes in a Cdc42 dependent fashion. The authors also found that these changes in lipid rafts stimulate inflammation through "re-localization of TLR4 and TREM-1 to rafts".

In summary, Nef-containing EVs can contribute to CVD both by increasing proteolytic and proinflammatory cargo and by intrinsic functions of the Nef protein (see also Figure 1). It would be interesting to study other viruses for a similar mechanism to employ EVs to control immune-related functions.

\section{Does the EVAIL Concept also Hold True for Other Viruses? What about Pandemic SARS CoV-2?}

It would be interesting to test whether mechanisms similar to HIV-Nef occur in other virus-related diseases. The COVID-19 respiratory illness is associated with pulmonary vascular thickening, endothelial dysfunction, thrombo-inflammation, and microthrombi [80,81]. Emerging findings suggest that COVID-19 patients, like HIV-infected patients, may be at higher risk of developing pulmonary hypertension in the future [82]. When A549 lung epithelial cells were transduced with lentivirus encoding SARS-CoV-2 proteins, exosomes are released carrying these viral proteins. The addition of these exosomes to recipient pluripotent stem cell-derived cardiomyocytes resulted in the entry of viral RNA into cardiomyocytes and increased expression of inflammatory genes [83]. It remains unclear whether these passed viral genes are biologically active and capable of inducing cell injury. It may be too speculative, but cellular recipients of EVs carrying viral proteins could be prone to becoming targets of autoimmune reactions.

Exosomes also have been reported to transfer ACE2, the receptor exploited by SARSCoV-2 for cell entry, to recipient cells [84]. Interestingly, a higher burden of EV-associated ACE2 is noted in SARS-CoV-2-infected patients without hypoxia than those requiring oxygen treatment. This finding suggests that EVs with ACE2 cargo might act as decoys, thereby reducing SARS-CoV-2 infection in epithelial cells $[85,86]$. Alternatively, EVs transporting ACE2 cargo may also render ACE2-negative cells, usually not targeted by SARS-CoV-2, to become infected with this virus. Although there is no apparent means of interfering with ACE2 transport by EVs, this is an essential finding that, depending on the membrane orientation of this receptor, could lead to antibody-directed detection and potential removal of COVID-19-related EVs.

It has been shown (see previous sections on HIV) that HIV-associated EVs carry HIV proteins and proinflammatory cargo that can be transferred to endothelial and other tissue recipient cells. Therefore, it would be interesting to explore whether this EV-mediated cargo transfer can also be observed with SARS-CoV-2-associated EVs. Our recent work has shown that EVs from patients infected with SARS-CoV-2 display higher levels of specific cytokines in correlation with disease severity. For example, large EVs from the plasma of patients with COVID-19 are enriched with multiple members of the TNF superfamily and 
their receptors and IL-6 family proteins [86]. These cytokines and their receptors are also characteristic of acquired respiratory distress syndrome (ARDS). Specifically, IL-6 has been associated with cytokine release in ARDS, septic shock, and COVID-19 [87-89]. Notably, the transfer of cytokine receptors could explain why EVs may add to inflammation despite the presence of already high concentrations of cytokines in COVID-19. This would imply that these cytokines receptors would be functionally integrated into the lipid bilayers of EVs. Of note, this is in contrast to soluble cytokine receptors in plasma, which typically result from proteolytic cleavage of the extracellular domains. Although uptake of these receptors has not yet been addressed in the study of COVID-19-associated EVs, it is a tempting speculation that COVID-19-related EVs could heighten the cytokine storm by increasing proinflammatory receptor densities in blood and other vascular cells.

The finding of increased IL-6 in COVID-19-associated EVs is significant because increased IL-6 plasma levels are part of predictor panels for cardiac events, especially in the setting of HIV infection [90-92]. In addition, higher levels of pro-inflammatory RAGE and EN-RAGE in EVs correlated with COVID-19 clinical severity could further provide a positive feedback loop for generating a cytokine storm [86]. Additionally, several proteins and proteases associated with cardiovascular disease and vascular remodeling, including prostatin, cathepsin L1, matrix metalloproteinase 9, and carboxypeptidases $1 / 2$ (CPA1/CPB1), are also upregulated in large EVs from patients with severe infection [86].

EVs, transiently released from injured cardiomyocytes, contain markers of early ischemic injury [93-95]. This release may comprise a mechanism by which some patients with COVID-19 experience elevated levels of circulating cardiac troponins (cTn). Lala et al. reported a significantly higher mortality risk among COVID-19 patients with even a tiny troponin leak [96]. EV-linked tissue factor (TF), a vital driver of the extrinsic coagulation cascade, is also elevated in COVID-19 patients with moderate [97] and severe disease [86]. Elevated TF in EV levels have been already linked to cancer-associated thrombosis [98] and now our work correlated EV-linked TF levels and activity with increasing COVID-19 disease severity and length of hospitalization [86]. This suggests that the prothrombotic and antithrombotic molecular profile of EVs from SARS-CoV-2-infected individuals may be one of the factors responsible for the increased risk of microthrombosis COVID-19 infection (see Figure 1). The long-term cardiovascular consequences of SARS-CoV-2 infection may result from an EV-mediated prothrombotic environment and endothelial activation and dysfunction. Notably, EVs may contribute to COVID-19 disease severity by adding increased proteolytic stress and procoagulant activation pathways to the already known increases in inflammatory cytokines. Additional research is needed to explore whether there is a role for EVs in propagating tissue destruction, inflammation, and thrombosis weeks to months out from COVID-19 diagnosis. Finally, it needs to be established whether EV cargo could become biomarkers for disease severity in COVID-19 or if distinct surface markers for COVID-19-associated EVs could be targeted for their therapeutic removal.

\section{Conclusions and Potential for Therapy}

This review focuses on a single protein, Nef, as an example of how viruses and their proteins can trigger the specific release of proinflammatory EVs. Although further studies targeting these EVs are required to provide more direct links to CVD, the potential of EVAIL to activate the endothelium is intriguing. It may be feasible to target the generation of EVAIL if we better understand the generation and uptake of EVs. Interestingly, EV-associated anti-inflammatory load has been described from mesenchymal stem cells (MSCs) $[99,100]$. The anti-inflammatory activities of MSC have emerged as an attractive anti-inflammatory strategy over the past decade [101-103]. In this article, MSCs were suggested to improve cardiovascular function and reduce the exuberant production of influenza-induced cytokines [102]. MSCs are already in clinical trials for treating COVID-19, and using EVs from these cells could be added to other already used MSC-based therapeutics. In addition, the incorporation of other anti-inflammatory and immune regulatory 
proteins like CD24 or cytokine-specific neutralizing therapeutic antibodies could lead to a novel platform of molecular therapies mediated by EVs.

Funding: This review was in part supported by a grant from the NIHBLI: 5R01HL154859-01 (to MC and ND).

Institutional Review Board Statement: Not applicable.

Informed Consent Statement: Not applicable.

Data Availability Statement: Not applicable.

Acknowledgments: Graphical Abstract was created on 6 May 2021 with BioRender.com.

Conflicts of Interest: The authors declare no conflict of interest.

\section{References}

1. Wang, H.; Peng, G.; Bai, J.; Kecheng, H.; Huang, K.; Hu, X.; Liu, D. Cytomegalovirus Infection and Relative Risk of Cardiovascular Disease (Ischemic Heart Disease, Stroke, and Cardiovascular Death): A Meta-Analysis of Prospective Studies Up to 2016. J. Am. Hear. Assoc. 2017, 6. [CrossRef] [PubMed]

2. Sackoff, J.E.; Hanna, D.B.; Pfeiffer, M.R.; Torian, L.V. Causes of Death among Persons with Aids in the Era of Highly Active Antiretroviral Therapy: New York City. Ann. Intern. Med. 2006, 145, 397-406. [CrossRef]

3. Freiberg, M.S.; Chang, C.-C.H.; Skanderson, M.; McGinnis, K.; Kuller, L.H.; Kraemer, K.L.; Rimland, D.; Goetz, M.B.; Butt, A.A.; Barradas, M.C.R.; et al. The Risk of Incident Coronary Heart Disease Among Veterans With and Without HIV and Hepatitis C. Circ. Cardiovasc. Qual. Outcomes 2011, 4, 425-432. [CrossRef] [PubMed]

4. Obel, N.; Thomsen, H.F.; Kronborg, G.; Larsen, C.S.; Hildebrandt, P.R.; Sørensen, H.T.; Gerstoft, J. Ischemic Heart Disease in HIV-Infected and HIV-Uninfected Individuals: A Population-Based Cohort Study. Clin. Infect. Dis. 2007, 44, 1625-1631. [CrossRef] [PubMed]

5. Triant, V.A.; Lee, H.; Hadigan, C.; Grinspoon, S.K. Increased Acute Myocardial Infarction Rates and Cardiovascular Risk Factors among Patients with Human Immunodeficiency Virus Disease. J. Clin. Endocrinol. Metab. 2007, 92, 2506-2512. [CrossRef] [PubMed]

6. Grunfeld, C.; Delaney, J.A.C.; Wanke, C.; Currier, J.S.; Scherzer, R.; Biggs, M.L.; Tien, P.C.; Shlipak, M.G.; Sidney, S.; Polak, J.F.; et al. Preclinical atherosclerosis due to HIV infection: Carotid intima-medial thickness measurements from the FRAM study. AIDS 2009, 23, 1841-1849. [CrossRef]

7. Mangili, A.; Polak, J.F.; Skinner, S.C.; Gerrior, J.; Sheehan, H.; Harrington, A.; Wanke, C.A. HIV Infection and Progression of Carotid and Coronary Atherosclerosis: The CARE Study. JAIDS J. Acquir. Immune Defic. Syndr. 2011, 58, 148-153. [CrossRef]

8. D'Ascenzo, F.; Quadri, G.; Cerrato, E.; Calcagno, A.; Omedé, P.; Marra, W.G.; Abbate, A.; Bonora, S.; Zoccai, G.B.; Moretti, C.; et al A meta-analysis investigating incidence and features of stroke in HIV-infected patients in the highly active antiretroviral therapy era. J. Cardiovasc. Med. 2015, 16, 839-843. [CrossRef]

9. Speich, R.; Jenni, R.; Opravil, M.; Pfab, M.; Russi, E.W. Primary Pulmonary Hypertension in Hiv Infection. Chest 1991, 100, 1268-1271. [CrossRef] [PubMed]

10. Sitbon, O.; Lascoux-Combe, C.; Delfraissy, J.-F.; Yeni, P.G.; Raffi, F.; De Zuttere, D.; Gressin, V.; Clerson, P.; Sereni, D.; Simonneau, G. Prevalence of HIV-related Pulmonary Arterial Hypertension in the Current Antiretroviral Therapy Era. Am. J. Respir. Crit. Care Med. 2008, 177, 108-113. [CrossRef]

11. Lang, S.; Mary-Krause, M.; Cotte, L.; Gilquin, J.; Partisani, M.; Simon, A.; Boccara, F.; Bingham, A.; Costagliola, D. Increased risk of myocardial infarction in HIV-infected patients in France, relative to the general population. AIDS 2010, 24, 1228-1230. [CrossRef]

12. Hsue, P.Y.; Hunt, P.W.; Ho, J.E.; Farah, H.H.; Schnell, A.; Hoh, R.; Martin, J.N.; Deeks, S.G.; Bolger, A.F. Impact of HIV Infection on Diastolic Function and Left Ventricular Mass. Circ. Hear. Fail. 2010, 3, 132-139. [CrossRef]

13. Durand, M.; Sheehy, O.; Baril, J.G.; Lelorier, J.; Tremblay, C.L. Association between Hiv Infection, Antiretroviral Therapy, and Risk of Acute Myocardial Infarction: A Cohort and Nested Case-Control Study Using Quebec's Public Health Insurance Database. J. Acquir. Immune Defic. Syndr. 2011, 57, 245-253. [CrossRef]

14. Butt, A.A.; Chang, C.-C.; Kuller, L.; Goetz, M.B.; Leaf, D.; Rimland, D.; Gibert, C.L.; Oursler, K.K.; Rodriguez-Barradas, M.C.; Lim, J.; et al. Risk of Heart Failure With Human Immunodeficiency Virus in the Absence of Prior Diagnosis of Coronary Heart Disease. Arch. Intern. Med. 2011, 171, 737-743. [CrossRef] [PubMed]

15. Sliwa, K.; Carrington, M.J.; Becker, A.; Thienemann, F.; Ntsekhe, M.; Stewart, S. Contribution of the human immunodeficiency virus/acquired immunodeficiency syndrome epidemic to de novo presentations of heart disease in the Heart of Soweto Study cohort. Eur. Hear. J. 2011, 33, 866-874. [CrossRef] [PubMed]

16. Lorgis, L.; Cottenet, J.; Molins, G.; Benzenine, E.; Zeller, M.; Aube, H.; Touzery, C.; Hamblin, J.; Gudjoncik, A.; Cottin, Y.; et al. Outcomes after Acute Myocardial Infarction in Hiv-Infected Patients: Analysis of Data from a French Nationwide Hospital Medical Information Database. Circulation 2013, 127, 1767-1774. [CrossRef] [PubMed] 
17. Freiberg, M.S.; Chang, C.-C.H.; Kuller, L.H.; Skanderson, M.; Lowy, E.; Kraemer, K.L.; Butt, A.A.; Goetz, M.B.; Leaf, D.; Oursler, K.A.; et al. HIV Infection and the Risk of Acute Myocardial Infarction. JAMA Intern. Med. 2013, 173, 614-622. [CrossRef] [PubMed]

18. Womack, J.A.; Chang, C.H.; So-Armah, K.; Alcorn, C.; Baker, J.V.; Brown, S.T.; Budoff, M.; Butt, A.A.; Gibert, C.; Goetz, M.B.; et al. HIV Infection and Cardiovascular Disease in Women. J. Am. Hear. Assoc. 2014, 3, e001035. [CrossRef]

19. Luo, L.; Zeng, Y.; Li, T.; Lv, W.; Wang, H.; Guo, F.; Han, Y.; Xie, J.; Qiu, Z.; Li, Y.; et al. Prospective Echocardiographic Assessment of Cardiac Structure and Function in Chinese Persons Living With HIV. Clin. Infect. Dis. 2014, 58, 1459-1466. [CrossRef]

20. Carvalho, R.F.; Mancio, J.; Marcos, A.; Sampaio, F.; Mota, M.; Gonçalves, F.R.; Gama, V.; Azevedo, A.; Leite-Moreira, A. HIV Patients Have Impaired Diastolic Function that is Not Aggravated by Anti-Retroviral Treatment. Cardiovasc. Drugs Ther. 2015, 29, 31-39. [CrossRef]

21. Rasmussen, L.D.; Helleberg, M.; May, M.T.; Afzal, S.; Kronborg, G.; Larsen, C.S.; Pedersen, C.; Gerstoft, J.; Nordestgaard, B.G.; Obel, N. Myocardial Infarction Among Danish HIV-Infected Individuals: Population-Attributable Fractions Associated With Smoking. Clin. Infect. Dis. 2015, 60, 1415-1423. [CrossRef] [PubMed]

22. Chow, D.; Young, R.; Valcour, N.; Kronmal, R.A.; Lum, C.J.; Parikh, N.I.; Tracy, R.P.; Budoff, M.J.; Shikuma, C.M. HIV and coronary artery calcium score: Comparison of the Hawaii Aging with HIV Cardiovascular Study and Multi-Ethnic Study of Atherosclerosis (MESA) cohorts. HIV Clin. Trials 2015, 16, 130-138. [CrossRef] [PubMed]

23. Al-Kindi, S.G.; ElAmm, C.; Ginwalla, M.; Mehanna, E.; Zacharias, M.; Benatti, R.; Oliveira, G.H.; Longenecker, C.T. Heart failure in patients with human immunodeficiency virus infection: Epidemiology and management disparities. Int. J. Cardiol. 2016, 218, 43-46. [CrossRef]

24. Freiberg, M.S.; Chang, C.H.; Skanderson, M.; Patterson, O.V.; DuVall, S.L.; Brandt, C.A.; So-Armah, K.A.; Vasan, R.S.; Oursler, K.A.; Gottdiener, J.; et al. Association between Hiv Infection and the Risk of Heart Failure with Reduced Ejection Fraction and Preserved Ejection Fraction in the Antiretroviral Therapy Era: Results from the Veterans Aging Cohort Study. JAMA Cardiol. 2017, 2, 536-546. [CrossRef] [PubMed]

25. Knudsen, A.D.; Gelpi, M.; Afzal, S.; Ronit, A.; Roen, A.; Mocroft, A.; Lundgren, J.; Nordestgaard, B.; Sillesen, H.; Lebech, A.-M.; et al. Brief Report: Prevalence of Peripheral Artery Disease Is Higher in Persons Living With HIV Compared With Uninfected Controls. JAIDS J. Acquir. Immune Defic. Syndr. 2018, 79, 381-385. [CrossRef]

26. Alonso, A.; Barnes, A.E.; Guest, J.L.; Shah, A.; Shao, I.Y.; Marconi, V. HIV Infection and Incidence of Cardiovascular Diseases: An Analysis of a Large Healthcare Database. J. Am. Hear. Assoc. 2019, 8, e012241. [CrossRef]

27. Beckman, J.A.; Duncan, M.S.; Alcorn, C.W.; So-Armah, K.; Butt, A.A.; Goetz, M.B.; Tindle, H.A.; Sico, J.J.; Tracy, R.P.; Justice, A.C.; et al. Association of Human Immunodeficiency Virus Infection and Risk of Peripheral Artery Disease. Circ. 2018, 138, 255-265. [CrossRef]

28. Rao, S.G.; Galaviz, K.I.; Gay, H.C.; Wei, J.; Armstrong, W.S.; del Rio, C.; Narayan, K.V.; Ali, M. Factors Associated With Excess Myocardial Infarction Risk in HIV-Infected Adults: A Systematic Review and Meta-analysis. JAIDS J. Acquir. Immune Defic. Syndr. 2019, 81, 224-230. [CrossRef]

29. Chattranukulchai, P.; Thimaporn, W.; Siwamogsatham, S.; Satitthunmmanid, S.; Sitticharoenchai, P.; Apornpong, T.; Sangarlangkarn, A.; Kerr, S.J.; Ruxrungtham, K.; Boonyaratavej, S.; et al. Echocardiographic Findings Among Virally Suppressed HIV-Infected Aging Asians Compared with HIV-Negative Individuals. JAIDS J. Acquir. Immune Defic. Syndr. 2020, 85, 379-386. [CrossRef]

30. Vallilo, N.G.; Durigon, G.S.; Lianza, A.C.; Diniz, M.d.R.; Sawamura, K.S.S.; Brito, C.R.; Marques, H.H.d.; Ferraro, A.A.; Leal, G.N. Echocardiographic Follow-up of Perinatally Hiv-Infected Children and Adolescents: Results from a Single-Center Retrospective Cohort Study in Brazil. Pediatr. Infect Dis. J. 2020, 39, 526-532. [CrossRef]

31. Shen, F.; Zhu, B.; Ding, Y.; Gao, M.; He, N. Electrocardiographic abnormalities among people with HIV in Shanghai, China. Biosci. Trends 2020, 14, 9-15. [CrossRef] [PubMed]

32. Kline, E.R.; Sutliff, R.L. The Roles of HIV-1 Proteins and Antiretroviral Drug Therapy in HIV-1-Associated Endothelial Dysfunction. J. Investig. Med. 2008, 56, 752-769. [CrossRef]

33. Baliga, R.S.; Chaves, A.A.; Jing, L.; Ayers, L.W.; Bauer, J.A. Aids-Related Vasculopathy: Evidence for Oxidative and Inflammatory Pathways in Murine and Human Aids. Am. J. Physiol. Heart Circ. Physiol. 2005, 289, H1373-H1380. [CrossRef] [PubMed]

34. Maggi, P.; Bellacosa, C.; Leone, A.; Volpe, A.; Ricci, E.D.; Ladisa, N.; Cicalini, S.; Grilli, E.; Viglietti, R.; Chirianni, A.; et al. Cardiovascular risk in advanced naïve HIV-infected patients starting antiretroviral therapy: Comparison of three different regimens-PREVALEAT II cohort. Atheroscler. 2017, 263, 398-404. [CrossRef] [PubMed]

35. Dinh, D.M.; Volpe, G.E.; Duffalo, C.; Bhalchandra, S.; Tai, A.K.; Kane, A.V.; Wanke, C.A.; Ward, H.D. Intestinal Microbiota, Microbial Translocation, and Systemic Inflammation in Chronic HIV Infection. J. Infect. Dis. 2015, 211, 19-27. [CrossRef]

36. Wallet, M.A.; Rodriguez, C.A.; Yin, L.; Saporta, S.; Chinratanapisit, S.; Hou, W.; Sleasman, J.W.; Goodenow, M.M. Microbial translocation induces persistent macrophage activation unrelated to HIV-1 levels or T-cell activation following therapy. AIDS 2010, 24, 1281-1290. [CrossRef]

37. Peterson, T.E.; Hullsiek, K.H.; Engen, N.W.; Kumarasamy, N.; Lebech, A.-M.; Liappis, A.; Papadopoulos, A.; Polizzotto, M.N.; Schreiner, P.J.; Duprez, D.; et al. Inflammation Associates With Impaired Small Arterial Elasticity Early in HIV Disease. Open Forum Infect. Dis. 2018, 5, 117. [CrossRef] 
38. Rönsholt, F.F.; Ullum, H.; Katzenstein, T.L.; Gerstoft, J.; Ostrowski, S.R. Persistent Inflammation and Endothelial Activation in HIV-1 Infected Patients after 12 Years of Antiretroviral Therapy. PLoS ONE 2013, 8, e65182. [CrossRef]

39. Lo, J. Dyslipidemia and lipid management in HIV-infected patients. Curr. Opin. Endocrinol. Diabetes Obes. 2011, 18, 144-147. [CrossRef]

40. Asztalos, B.F.; Mujawar, Z.; Morrow, M.P.; Grant, A.; Pushkarsky, T.; Wanke, C.; Shannon, R.; Geyer, M.; Kirchhoff, F.; Sviridov, D.; et al. Circulating Nef Induces Dyslipidemia in Simian Immunodeficiency Virus-Infected Macaques by Suppressing Cholesterol Efflux. J. Infect. Dis. 2010, 202, 614-623. [CrossRef]

41. Cui, H.L.; Ditiatkovski, M.; Kesani, R.; Bobryshev, Y.V.; Liu, Y.; Geyer, M.; Mukhamedova, N.; Bukrinsky, M.; Sviridov, D. HIV protein Nef causes dyslipidemia and formation of foam cells in mouse models of atherosclerosis. FASEB J. 2014, 28, $2828-2839$. [CrossRef] [PubMed]

42. Mujawar, Z.; Tamehiro, N.; Grant, A.; Sviridov, D.; Bukrinsky, M.; Fitzgerald, M.L. Mutation of the ATP Cassette Binding Transporter A1 (ABCA1) C-Terminus Disrupts HIV-1 Nef Binding but Does Not Block the Nef Enhancement of ABCA1 Protein Degradation. Biochemistry 2010, 49, 8338-8349. [CrossRef]

43. Sharma, H.; Chinnappan, M.; Agarwal, S.; Dalvi, P.; Gunewardena, S.; O’Brien-Ladner, A.; Dhillon, N.K. Macrophage-derived extracellular vesicles mediate smooth muscle hyperplasia: Role of altered miRNA cargo in response to HIV infection and substance abuse. FASEB J. 2018, 32, 5174-5185. [CrossRef]

44. Chettimada, S.; Lorenz, D.R.; Misra, V.; Wolinsky, S.M.; Gabuzda, D. Small RNA sequencing of extracellular vesicles identifies circulating miRNAs related to inflammation and oxidative stress in HIV patients. BMC Immunol. 2020, 21, 1-20. [CrossRef] [PubMed]

45. Krishnamachary, B.; Mahajan, A.; Kumar, A.; Agarwal, S.; Mohan, A.; Chen, L.; Hsue, P.; Chalise, P.; Morris, A.; Dhillon, N.K. Extracellular Vesicle Tgf-Beta1 Is Linked to Cardiopulmonary Dysfunction in Hiv. Am. J. Respir. Cell Mol. Biol. 2021. [CrossRef]

46. Chelvanambi, S.; Bogatcheva, N.V.; Bednorz, M.; Agarwal, S.; Maier, B.; Alves, N.J.; Li, W.; Syed, F.; Saber, M.M.; Dahl, N.; et al. HIV-Nef Protein Persists in the Lungs of Aviremic Patients with HIV and Induces Endothelial Cell Death. Am. J. Respir. Cell Mol. Biol. 2019, 60, 357-366. [CrossRef] [PubMed]

47. Chelvanambi, S.; Gupta, S.K.; Chen, X.; Ellis, B.W.; Maier, B.F.; Colbert, T.M.; Kuriakose, J.; Zorlutuna, P.; Jolicoeur, P.; Obukhov, A.G.; et al. HIV-Nef Protein Transfer to Endothelial Cells Requires Rac1 Activation and Leads to Endothelial Dysfunction Implications for Statin Treatment in HIV Patients. Circ. Res. 2019, 125, 805-820. [CrossRef]

48. Wang, T.; Green, L.A.; Gupta, S.K.; Kim, C.; Wang, L.; Almodovar, S.; Flores, S.C.; Prudovsky, I.A.; Jolicoeur, P.; Liu, Z.; et al. Transfer of Intracellular HIV Nef to Endothelium Causes Endothelial Dysfunction. PLoS ONE 2014, 9, e91063. [CrossRef] [PubMed]

49. Ali, S.A.; Huang, M.-B.; Campbell, P.E.; Roth, W.W.; Campbell, T.; Khan, M.; Newman, G.; Villinger, F.; Powell, M.D.; Bond, V.C. Genetic Characterization of HIV Type 1 Nef-Induced Vesicle Secretion. AIDS Res. Hum. Retrovir. 2010, 26, 173-192. [CrossRef] [PubMed]

50. Arenaccio, C.; Chiozzini, C.; Columba-Cabezas, S.; Manfredi, F.; Affabris, E.; Baur, A.; Federico, M. Exosomes from Human Immunodeficiency Virus Type 1 (HIV-1)-Infected Cells License Quiescent CD4 + T Lymphocytes To Replicate HIV-1 through a Nef- and ADAM17-Dependent Mechanism. J. Virol. 2014, 88, 11529-11539. [CrossRef] [PubMed]

51. Campbell, T.D.; Khan, M.; Huang, M.-B.; Bond, V.C.; Powell, M.D. HIV-1 Nef protein is secreted into vesicles that can fuse with target cells and virions. Ethn. Dis. 2008, 18, S2-14-9.

52. Lenassi, M.; Cagney, G.; Liao, M.; Vaupotič, T.; Bartholomeeusen, K.; Cheng, Y.; Krogan, N.J.; Plemenitaš, A.; Peterlin, B. HIV Nef is secreted in exosomes and triggers apoptosis in bystander CD4+ T cells. Traffic 2010, 11, 110-122. [CrossRef]

53. Mohan, A.; Agarwal, S.; Clauss, M.; Britt, N.S.; Dhillon, N.K. Extracellular vesicles: Novel communicators in lung diseases. Respir. Res. 2020, 21, 175. [CrossRef] [PubMed]

54. Chen, L.; Feng, Z.; Yue, H.; Bazdar, D.; Mbonye, U.; Zender, C.; Harding, C.V.; Bruggeman, L.; Karn, J.; Sieg, S.F.; et al. Exosomes derived from HIV-1-infected cells promote growth and progression of cancer via HIV TAR RNA. Nat. Commun. 2018, 9, 1-12. [CrossRef] [PubMed]

55. Ellwanger, J.H.; Veit, T.D.; Chies, J.A.B. Exosomes in HIV infection: A review and critical look. Infect. Genet. Evol. 2017, 53, 146-154. [CrossRef] [PubMed]

56. Gangoda, L.; Boukouris, S.; Liem, M.; Kalra, H.; Mathivanan, S. Extracellular vesicles including exosomes are mediators of signal transduction: Are they protective or pathogenic? Proteom. 2015, 15, 260-271. [CrossRef] [PubMed]

57. Hildreth, J.E.K. HIV As Trojan Exosome: Immunological Paradox Explained? Front. Immunol. 2017, 8, 1715. [CrossRef]

58. Kodidela, S.; Gerth, K.; Haque, S.; Gong, Y.; Ismael, S.; Singh, A.; Ishrat, T.; Kumar, S. Extracellular Vesicles: A Possible Link between HIV and Alzheimer's Disease-Like Pathology in HIV Subjects? Cells 2019, 8, 968. [CrossRef]

59. Konadu, K.A.; Chu, J.; Huang, M.B.; Amancha, P.K.; Armstrong, W.S.; Powell, M.D.; Villinger, F.; Bond, V.C. Association of Cytokines With Exosomes in the Plasma of HIV-1-Seropositive Individuals. J. Infect. Dis. 2015, 211, 1712-1716. [CrossRef]

60. Li, H.; Chi, X.; Li, R.; Ouyang, J.; Chen, Y. HIV-1-infected cell-derived exosomes promote the growth and progression of cervical cancer. Int. J. Biol. Sci. 2019, 15, 2438-2447. [CrossRef]

61. Madison, M.N.; Okeoma, C.M. Exosomes: Implications in HIV-1 Pathogenesis. Viruses 2015, 7, 4093-4118. [CrossRef] 
62. Lee, J.-H.; Schierer, S.; Blume, K.; Dindorf, J.; Wittki, S.; Xiang, W.; Ostalecki, C.; Koliha, N.; Wild, S.; Schuler, G.; et al. HIV-Nef and ADAM17-containing plasma extracellular vesicles induce and correlate with immune pathogenesis in chronic HIV infection. EBioMedicine 2016, 6, 103-113. [CrossRef]

63. Chettimada, S.; Lorenz, D.R.; Misra, V.; Dillon, S.T.; Reeves, R.K.; Manickam, C.; Morgello, S.; Kirk, G.D.; Mehta, S.H.; Gabuzda, D. Exosome markers associated with immune activation and oxidative stress in HIV patients on antiretroviral therapy. Sci. Rep. 2018, 8, 1-16. [CrossRef] [PubMed]

64. Fischer, M.; Joos, B.; Niederost, B.; Kaiser, P.; Hafner, R.; Von Wyl, V.; Ackermann, M.; Weber, R.; Gunthard, H.F. Biphasic decay kinetics suggest progressive slowing in turnover of latently HIV-1 infected cells during antiretroviral therapy. Retrovirology 2008, 5, 107. [CrossRef]

65. Fischer, M.; Joos, B.; Hirschel, B.; Bleiber, G.; Weber, R.; Gunthard, H.F. Cellular Viral Rebound after Cessation of Potent Antiretroviral Therapy Predicted by Levels of Multiply Spliced Hiv-1 Rna Encoding Nef. J. Infect. Dis. 2004, 190, 1979-1988. [CrossRef]

66. Raymond, A.; Campbell-Sims, T.; Khan, M.A.K.G.; Lang, M.; Huang, M.B.; Bond, V.C.; Powell, M.D. HIV Type 1 Nef Is Released from Infected Cells in CD45+Microvesicles and Is Present in the Plasma of HIV-Infected Individuals. AIDS Res. Hum. Retrovir. 2011, 27, 167-178. [CrossRef] [PubMed]

67. Wang, T.; Green, L.A.; Gupta, S.K.; Amet, T.; Byrd, D.J.; Yu, Q.; Twigg, H.L., 3rd; Clauss, M. Intracellular Nef Detected in Peripheral Blood Mononuclear Cells from Hiv Patients. AIDS Res. Hum. Retrovir. 2015, 31, 217-220. [CrossRef] [PubMed]

68. Ferdin, J.; Goričar, K.; Dolžan, V.; Plemenitaš, A.; Martin, J.N.; Peterlin, B.M.; Deeks, S.; Lenassi, M. Viral protein Nef is detected in plasma of half of HIV-infected adults with undetectable plasma HIV RNA. PLoS ONE 2018, 13, e0191613. [CrossRef] [PubMed]

69. Lee, J.H.; Wittki, S.; Brau, T.; Dreyer, F.S.; Kratzel, K.; Dindorf, J.; Johnston, I.C.; Gross, S.; Kremmer, E.; Zeidler, R.; et al. Hiv Nef, Paxillin, and Pak1/2 Regulate Activation and Secretion of Tace/Adam10 Proteases. Mol. Cell 2013, 49, 668-679. [CrossRef]

70. Ostalecki, C.; Wittki, S.; Lee, J.-H.; Geist, M.M.; Tibroni, N.; Harrer, T.; Schuler, G.; Fackler, O.; Baur, A.S. HIV Nef- and Notch1dependent Endocytosis of ADAM17 Induces Vesicular TNF Secretion in Chronic HIV Infection. EBioMedicine 2016, 13, 294-304. [CrossRef] [PubMed]

71. Gooz, M. ADAM-17: The enzyme that does it all. Crit. Rev. Biochem. Mol. Biol. 2010, 45, 146-169. [CrossRef] [PubMed]

72. Arenaccio, C.; Anticoli, S.; Manfredi, F.; Chiozzini, C.; Olivetta, E.; Federico, M. Latent HIV-1 is activated by exosomes from cells infected with either replication-competent or defective HIV-1. Retrovirology 2015, 12, 1-17. [CrossRef]

73. Tang, X.; Lu, H.; Dooner, M.; Chapman, S.; Quesenberry, P.J.; Ramratnam, B. Exosomal Tat protein activates latent HIV-1 in primary, resting CD4+ T lymphocytes. JCI Insight 2018, 3. [CrossRef]

74. McNamara, R.P.; Costantini, L.M.; Myers, T.A.; Schouest, B.; Maness, N.J.; Griffith, J.D.; Damania, B.A.; MacLean, A.G.; Dittmer, D.P. Nef Secretion into Extracellular Vesicles or Exosomes Is Conserved across Human and Simian Immunodeficiency Viruses. mBio 2018, 9. [CrossRef]

75. Saribas, A.S.; Cicalese, S.; Ahooyi, T.M.; Khalili, K.; Amini, S.; Sariyer, I.K. HIV-1 Nef is released in extracellular vesicles derived from astrocytes: Evidence for Nef-mediated neurotoxicity. Cell Death Dis. 2018, 8, e2542. [CrossRef]

76. Khan, M.B.; Lang, M.J.; Huang, M.B.; Raymond, A.; Bond, V.C.; Shiramizu, B.; Powell, M.D. Nef Exosomes Isolated from the Plasma of Individuals with Hiv-Associated Dementia (Had) Can Induce Abeta(1-42) Secretion in Sh-Sy5y Neural Cells. J. Neurovirol. 2016, 22, 179-190. [CrossRef]

77. Raymond, A.D.; Diaz, P.; Chevelon, S.; Agudelo, M.; Yndart-Arias, A.; Ding, H.; Kaushik, A.; Jayant, R.D.; Nikkhah-Moshaie, R.; Roy, U.; et al. Microglia-derived HIV Nef+ exosome impairment of the blood-brain barrier is treatable by nanomedicine-based delivery of Nef peptides. J. NeuroVirology 2016, 22, 129-139. [CrossRef]

78. Eckard, A.R.; Mccomsey, G.A. The Role of Statins in the Setting of HIV Infection. Curr. HIV/AIDS Rep. 2015, 12, 305-312. [CrossRef] [PubMed]

79. Mukhamedova, N.; Hoang, A.; Dragoljevic, D.; Dubrovsky, L.; Pushkarsky, T.; Low, H.; Ditiatkovski, M.; Fu, Y.; Ohkawa, R.; Meikle, P.J.; et al. Exosomes containing HIV protein Nef reorganize lipid rafts potentiating inflammatory response in bystander cells. PLoS Pathog. 2019, 15, e1007907. [CrossRef]

80. Lowenstein, C.J.; Solomon, S.D. Severe COVID-19 is a Microvascular Disease. Circulation 2020, 142, 1609-1611. [CrossRef] [PubMed]

81. Potus, F.; Mai, V.; Lebret, M.; Malenfant, S.; Breton-Gagnon, E.; Lajoie, A.C.; Boucherat, O.; Bonnet, S.; Provencher, S. Novel insights on the pulmonary vascular consequences of COVID-19. Am. J. Physiol. Cell. Mol. Physiol. 2020, 319, L277-L288. [CrossRef] [PubMed]

82. Suzuki, Y.J.; Nikolaienko, S.I.; Shults, N.V.; Gychka, S.G. COVID-19 patients may become predisposed to pulmonary arterial hypertension. Med. Hypotheses 2021, 147, 110483. [CrossRef] [PubMed]

83. Kwon, Y.; Nukala, S.B.; Srivastava, S.; Miyamoto, H.; Ismail, N.I.; Jousma, J.; Rehman, J.; Ong, S.B.; Lee, W.H.; Ong, S.G. Detection of Viral Rna Fragments in Human Ipsc Cardiomyocytes Following Treatment with Extracellular Vesicles from Sars-Cov-2 Coding Sequence Overexpressing Lung Epithelial Cells. Stem. Cell Res. Ther. 2020, 11, 514. [CrossRef] [PubMed]

84. Yang, X.; Yu, Y.; Xu, J.; Shu, H.; Xia, J.; Liu, H.; Wu, Y.; Zhang, L.; Yu, Z.; Fang, M.; et al. Clinical Course and Outcomes of Critically Ill Patients with Sars-Cov-2 Pneumonia in Wuhan, China: A Single-Centered, Retrospective, Observational Study. Lancet Respir. Med. 2020, 8, 475-481. [CrossRef] 
85. Cocozza, F.; Nevo, N.; Piovesana, E.; Lahaye, X.; Buchrieser, J.; Schwartz, O.; Manel, N.; Tkach, M.; Thery, C.; Martin-Jaular, L. Extracellular Vesicles Containing Ace2 Efficiently Prevent Infection by Sars-Cov-2 Spike Protein-Containing Virus. J. Extracell. Vesicles 2020, 10, e12050. [CrossRef] [PubMed]

86. Krishnamachary, B.; Cook, C.; Spikes, L.; Chalise, P.; Dhillon, N.K. The Potential Role of Extracellular Vesicles in Covid-19 Associated Endothelial Injury and Pro-Inflammation. medRxiv 2020. [CrossRef]

87. Abbasifard, M.; Khorramdelazad, H. The bio-mission of interleukin-6 in the pathogenesis of COVID-19: A brief look at potential therapeutic tactics. Life Sci. 2020, 257, 118097. [CrossRef]

88. Arunachalam, P.S.; Wimmers, F.; Mok, C.K.P.; Perera, R.A.P.M.; Scott, M.; Hagan, T.; Sigal, N.; Feng, Y.; Bristow, L.; Tsang, O.T.-Y.; et al. Systems biological assessment of immunity to mild versus severe COVID-19 infection in humans. Science 2020, 369, 1210-1220. [CrossRef]

89. Favalli, E.G. Understanding the Role of Interleukin-6 (IL-6) in the Joint and Beyond: A Comprehensive Review of IL-6 Inhibition for the Management of Rheumatoid Arthritis. Rheumatol. Ther. 2020, 7, 473-516. [CrossRef]

90. Blake, G.J.; Ridker, P.M. C-reactive protein and other inflammatory risk markers in acute coronary syndromes. J. Am. Coll. Cardiol. 2003, 41, S37-S42. [CrossRef]

91. Lee, K.W.; Blann, A.D.; Lip, G.Y. Plasma markers of endothelial damage/dysfunction, inflammation and thrombogenesis in relation to TIMI risk stratification in acute coronary syndromes. Thromb. Haemost. 2005, 94, 1077-1083. [CrossRef] [PubMed]

92. Borges, Á.H.; O'Connor, J.L.; Phillips, A.N.; Neaton, J.D.; Grund, B.; Neuhaus, J.; Vjecha, M.J.; Calmy, A.; Koelsch, K.K.; Lundgren, J.D. Interleukin 6 Is a Stronger Predictor of Clinical Events Than High-Sensitivity C-Reactive Protein or D-Dimer During HIV Infection. J. Infect. Dis. 2016, 214, 408-416. [CrossRef] [PubMed]

93. Mair, J.; Lindahl, B.; Hammarsten, O.; Müller, C.; Giannitsis, E.; Huber, K.; Möckel, M.; Plebani, M.; Thygesen, K.; Jaffe, A.S. How is cardiac troponin released from injured myocardium? Eur. Hear. J. Acute Cardiovasc. Care 2018, 7, 553-560. [CrossRef] [PubMed]

94. Schwartz, P.; Piper, H.M.; Spahr, R.; Spieckermann, P.G. Ultrastructure of cultured adult myocardial cells during anoxia and reoxygenation. Am. J. Pathol. 1984, 115, 349-361.

95. Hickman, P.E.; Potter, J.M.; Aroney, C.; Koerbin, G.; Southcott, E.; Wu, A.H.; Roberts, M. Cardiac troponin may be released by ischemia alone, without necrosis. Clin. Chim. Acta 2010, 411, 318-323. [CrossRef]

96. Lala, A.; Johnson, K.; Januzzi, J.L.; Russak, A.J.; Paranjpe, I.; Richter, F.; Zhao, S.; Somani, S.; Van Vleck, T.; Vaid, A.; et al. Prevalence and Impact of Myocardial Injury in Patients Hospitalized With COVID-19 Infection. J. Am. Coll. Cardiol. 2020, 76, 533-546. [CrossRef]

97. Rosell, A.; Havervall, S.; Von Meijenfeldt, F.; Hisada, Y.; Aguilera, K.; Grover, S.P.; Lisman, T.; Mackman, N.; Thålin, C. Patients With COVID-19 Have Elevated Levels of Circulating Extracellular Vesicle Tissue Factor Activity That Is Associated With Severity and Mortality-Brief Report. Arterioscler. Thromb. Vasc. Biol. 2021, 41, 878-882. [CrossRef]

98. Lacroix, R.; Vallier, L.; Bonifay, A.; Simoncini, S.; Mege, D.; Aubert, M.; Panicot-Dubois, L.; Dubois, C.; Dignat-George, F. Microvesicles and Cancer Associated Thrombosis. Semin. Thromb. Hemost. 2019, 45, 593-603. [CrossRef]

99. Chen, W.; Huang, Y.; Han, J.; Yukai, H.; Li, Y.; Lu, Z.; Li, H.; Liu, Z.; Shi, C.; Duan, F.; et al. Immunomodulatory effects of mesenchymal stromal cells-derived exosome. Immunol. Res. 2016, 64, 831-840. [CrossRef]

100. Iyer, S.S.; Rojas, M. Anti-inflammatory effects of mesenchymal stem cells: Novel concept for future therapies. Expert Opin. Biol. Ther. 2008, 8, 569-581. [CrossRef]

101. Abreu, S.C.; Weiss, D.J.; Rocco, P.R.M. Extracellular vesicles derived from mesenchymal stromal cells: A therapeutic option in respiratory diseases? Stem Cell Res. Ther. 2016, 7, 1-10. [CrossRef] [PubMed]

102. Cheng, Y.; Cao, X.; Qin, L. Mesenchymal Stem Cell-Derived Extracellular Vesicles: A Novel Cell-Free Therapy for Sepsis. Front. Immunol. 2020, 11, 647. [CrossRef] [PubMed]

103. Gardin, C.; Ferroni, L.; Chachques, J.C.; Zavan, B. Could Mesenchymal Stem Cell-Derived Exosomes Be a Therapeutic Option for Critically Ill COVID-19 Patients? J. Clin. Med. 2020, 9, 2762. [CrossRef] [PubMed] 